NOTICE: this is the author's version of a work that was accepted for publication in the journal Lithos. Changes resulting from the publishing process, such as peer review, editing, corrections, structural formatting, and other quality control mechanisms may not be reflected in this document. Changes may have been made to this work since it was submitted for publication. A definitive version was subsequently published in the journal Lithos, Vol.206-207, (2014). DOI: 10.1016/j.lithos.2014.08.005 


\title{
Retention of radiation damage in zircon xenocrysts from kimberlites, Northern Yakutia
}

\author{
Lutz Nasdala $^{\text {a,* }}$, Sergey Kostrovitsky ${ }^{\mathrm{b}}$, Allen K. Kennedy ${ }^{\mathrm{c}}$, Manuela Zeug ${ }^{\text {a }}$, Svetlana A. Esenkulova ${ }^{\mathrm{b}}$ \\ a Institut für Mineralogie und Kristallographie, Universität Wien, A - 1090 Wien, Austria \\ b Vinogradov Institute of Geochemistry, Siberian Branch, Russian Academy of Sciences, Irkutsk 664033, Russia \\ c Department of Imaging and Applied Physics, Curtin University of Technology, Perth, WA 6102, Australia
}

\section{A R T I C L E I N F O}

\section{Article history:}

Received 17 March 2014

Accepted 6 August 2014

Available online 13 August 2014

\section{Keywords:}

Xenocrystic zircon

Kimberlite

Yakutia

Annealing

SHRIMP U-Th-Pb ages

\begin{abstract}
A B S T R A C T
We have studied zircon xenocrysts from Mesozoic kimberlites from the Kuoika and Ary-Mastakh fields in Northern Yakutia. Zircon xenocrysts are assumed to originate from crustal rocks. Our SHRIMP (Sensitive High mass Resolution Ion MicroProbe) analyses yielded predominantly concordant $\mathrm{U}-\mathrm{Th}-\mathrm{Pb}$ ages (up to $~ 3570 \mathrm{Ma}$; Paleoarchean) that clearly predate kimberlite formation. The general U-Th-Pb concordance observed excludes notable disturbance of the zircon xenocrysts $\mathrm{U}-\mathrm{Th}-\mathrm{Pb}$ isotope system during kimberlite ascent and emplacement. In addition, zircon xenocrysts were found to be significantly more radiation-damaged than would correspond to damage accumulation only since the time of kimberlite formation. This observation first indicates that zircon crystals were sampled by the kimberlite magma at comparably shallow depths not exceeding 10-12 km. If, in contrast, zircon crystals originated from deeper levels of the Earth's crust, they would have been exposed to temperatures of $250-300{ }^{\circ} \mathrm{C}$ or more. This in turn would have caused long-term thermal annealing of the radiation damage, which was however not observed in our study. Second, our observation contradicts the hypothesis that high temperatures experienced by zircon xenocrysts during kimberlite ascent will cause notable structural reconstitution by short-term thermal annealing. Consequently, zircon crystals cannot have spent more than a few hours at temperatures exceeding ca. $700-800{ }^{\circ} \mathrm{C}$, or more than a few days at temperatures exceeding ca. $500-600{ }^{\circ} \mathrm{C}$. This in turn suggests that (i) temperatures of the ascending kimberlite magmas were rather moderate, and (ii) kimberlite ascent is a comparably short process followed by rapid cooling.
\end{abstract}

(c) 2014 Elsevier B.V. All rights reserved.

\section{Introduction}

Kimberlite pipes in the Siberian Platform commonly contain zircon crystals, which belong to two groups. First, there are large grains with sizes ranging between ca. $300 \mu \mathrm{m}$ and several centimetres, whose growth is related to kimberlite formation. Second, there are numerous smaller grains (sizes typically $<300 \mu \mathrm{m}$ ) that are xenocrysts. The latter originate from rocks of the basement and/or lithospheric mantle, which were crushed and captured by the ascending kimberlite magma. In the Siberian Platform, zircon xenocrysts derived from crustal material originate predominantly from granulite xenoliths in the lower crust of the Siberian Craton (Buzlukova et al., 2004; Neymark et al., 1992; Rosen et al., 2002; Shatsky et al., 1990). Favoured by the physical stability and chemical and thermal resistance of zircon, such xenocrysts may yield a wealth of information on their primary rocks, and the milieu of conditions of kimberlite-magma formation (Koreshkova et al., 2009; Kostrovitsky et al., 2013; Vladykin and Lepekhina, 2009).

Here we report results of a study on zircon xenocrysts from kimberlite pipes in the Kuoika and Ary-Mastakh fields, Northern

\footnotetext{
* Corresponding author. Tel.: +4314277 53220.

E-mail address: lutz.nasdala@univie.ac.at (L. Nasdala).
}

Yakutia. The Kuoiksky field is located in the northeast of the Yakutian kimberlite province, in the lower section of the Olenek River (Fig. 1). It belongs to the Birehtinsk granite-greenstone terrane (Rosen, 2003). The Kuoika field is particularly rich in kimberlites; about one hundred pipes and dykes have been found thus far. The Ary-Mastakh field is located at the southeastern boundary of the Anabar shield (Fig. 1). Within the field there are about 40 pipes composed of kimberlites and alkaline picrites. Mesozoic ages for kimberlite pipes have been reported in the literature, based on $\mathrm{U}-\mathrm{Pb}$ analyses of perovskite and zircon (Griffin et al., 1999; Kinny et al., 1997; Zaitsev and Smelov, 2010). Recent analyses yielded 170-150 Ma for Kuoika kimberlites, and two formation intervals (230-210 Ma and 170-160 Ma) for Ary-Mastakh kimberlites (Sun et al., 2014). Almost all pipes of the Kuoika and Ary-Mastakh fields were found to contain notable amounts of zircon xenocrysts in their heavy mineral fractions (Kostrovitsky, 1986; Kostrovitsky et al., 2013).

This present paper addresses the question as to what degree zircon xenocrysts are affected by the thermal impact of being sampled and transported to the Earth's surface by the hot kimberlite magma. In particular, possible thermal-annealing effects on the radiation damage that was accumulated prior to the kimberlite-formation event were focused on. 


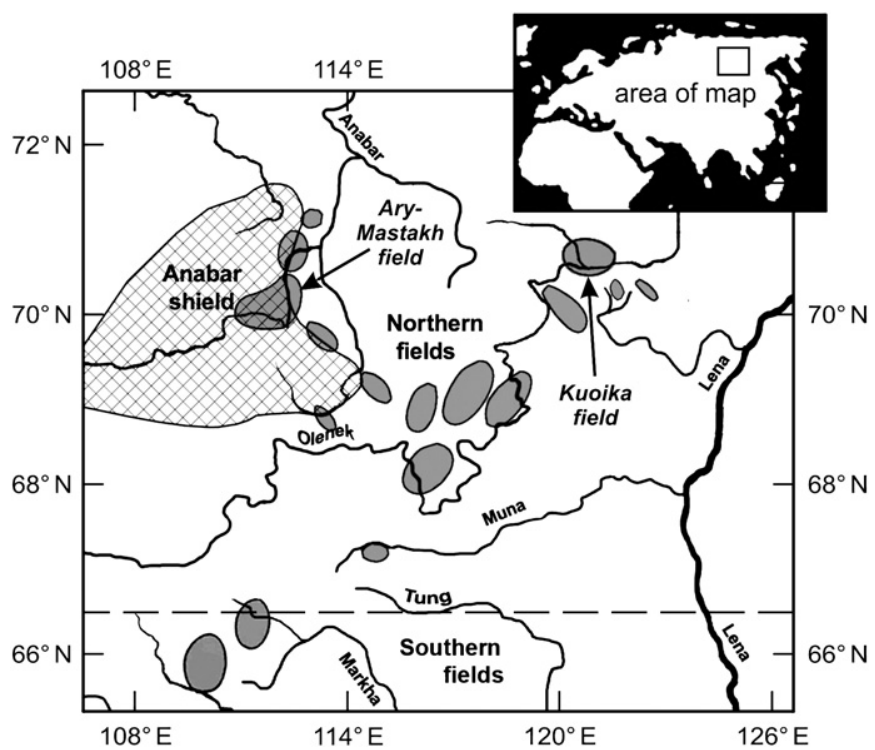

Fig. 1. Simplified map of a part of the Yakutian province, showing the locations of the AryMastakh and Kuoika fields. Kimberlite fields are highlighted in grey.

Figure from Kharkiv et al. (1998), substantially modified.

\section{Background information: evaluation of damage retention}

The cause of natural radiation damage, i.e. alpha-decay events experienced by zircon, is usually quantified for geological samples by the time-integrated alpha dose $\mathrm{D}_{\alpha}$. It is calculated (Murakami et al., 1991) according to

$$
\begin{aligned}
\mathrm{D}_{\alpha}= & 8 \cdot \frac{\mathrm{c}_{\mathrm{U}} \cdot \mathrm{N}_{\mathrm{A}} \cdot 0.9928}{\mathrm{M}_{238} \cdot 10^{6}} \cdot\left(\mathrm{e}^{\lambda_{238} \mathrm{t}}-1\right)+7 \cdot \frac{\mathrm{c}_{\mathrm{U}} \cdot \mathrm{N}_{\mathrm{A}} \cdot 0.0072}{\mathrm{M}_{235} \cdot 10^{6}} \cdot\left(\mathrm{e}^{\lambda_{235} \mathrm{t}}-1\right) \\
& +6 \cdot \frac{\mathrm{c}_{\mathrm{Th}} \cdot \mathrm{N}_{\mathrm{A}}}{\mathrm{M}_{232} \cdot 10^{6}} \cdot\left(\mathrm{e}^{\lambda_{232} \mathrm{t}}-1\right)
\end{aligned}
$$

with $\mathrm{c}_{\mathrm{U}}$ and $\mathrm{c}_{\mathrm{Th}}=$ present actinide concentrations (in $\mu \mathrm{g} / \mathrm{g}$ ), $\mathrm{NA}=$ Avogadro's number, $\mathrm{M}_{238}, \mathrm{M}_{235}$, and $\mathrm{M}_{232}=$ molecular weights of the parent isotopes, $\lambda_{238}, \lambda_{235}$, and $\lambda_{232}=$ decay constants of parent isotopes, and $\mathrm{t}=$ integration time. The equation above assumes a present-day uranium composition of $\sim 99.28 \%{ }^{238} \mathrm{U}$ and $\sim 0.72 \%{ }^{235} \mathrm{U}$ (Cowan and Adler, 1976).

The calculated alpha dose, however, does in fact rarely correspond to the alpha-event damage present. This is because radiation damage may have been annealed, depending on the sample's thermal history (see detailed discussion by Nasdala et al., 2001). On the contrary, the comparison of the theoretical maximum damage, indicated by calculated alpha doses, and the damage actually present, provides information on the degree of damage storage by a given zircon.

The degree of the radiation damage present can be estimated on a micrometre-scale using Raman spectroscopy (Nasdala et al., 1995). For this purpose, the FWHM (full width at half-maximum) of the intense $v_{3}\left(\mathrm{SiO}_{4}\right)$ Raman band of zircon $\left(\mathrm{B}_{1 \mathrm{~g}}\right.$ mode near $1000 \mathrm{~cm}^{-1}$ assigned to anti-symmetric stretching of $\mathrm{SiO}_{4}$ tetrahedrons; Dawson et al., 1971; Syme et al., 1977) is measured. This parameter changes from $\sim 1.8 \mathrm{~cm}^{-1}$ for well-crystallised zircon (Nasdala et al., 2002) to well above $30 \mathrm{~cm}^{-1}$ for strongly damaged zircon.

Quantitative estimates of the degree of damage retention in unknowns are made by comparing the damage actually present with the theoretical maximum damage. This is possible by comparing FWHM$\mathrm{D}_{\alpha}$ data pairs of unknowns with those of unannealed zircon samples (Nasdala et al., 2001). To elucidate how such comparison may provide an estimate of the damage retention, and hence yield valuable conclusions on the thermal history of unknowns, we present two examples in Fig. 2a-c. In the present study, we apply this method to study whether or not the temperature increase in the kimberlite magma has caused major annealing of the previously accumulated radiation damage in zircon xenocrysts.

Data pairs for metamorphic zircon from a sillimanite-biotite gneiss from Val Strona, Ivrea Zone, Italian Alps (Vavra et al., 1999) and those of unannealed zircon (Nasdala et al., 2001) show a clear mismatch (Fig. 2a) if $\mathrm{D}_{\alpha}$ values for the Ivrea zircon are calculated assuming selfirradiation since the time of closure of the U-Th-Pb system. Consequently, the Ivrea zircon is much less radiation-damaged as would correspond to complete damage accumulation since the time of the high-grade metamorphic zircon growth. This in turn indicates a significant annealing history. However, FWHM- $\mathrm{D}_{\alpha}$ data pairs of Ivrea zircon and unannealed references match reasonably well (Fig. $2 b$ ) if $\mathrm{D}_{\alpha}$ values for the Ivrea zircon are calculated based on the 31 Ma age of the Cenozoic uplift (Hurford et al., 1989). Both observations together suggest that after metamorphic growth, the Ivrea zircon may have resided at considerable depths below the Earth's surface for an extended period of time, undergoing continuous thermal annealing. Damage accumulation started only at the time of the Cenozoic uplift of the Alps (Nasdala et al., 2001).

In contrast, FWHM- $\mathrm{D}_{\alpha}$ data pairs for zircon from Plešovice (wellknown as a $\mathrm{U}-\mathrm{Pb}$ and $\mathrm{Hf}$ isotope reference material; Sláma et al., 2008) correlate with FWHM-D $\mathrm{D}_{\alpha}$ data pairs of unannealed zircon, with time-integrated alpha doses of the Plešovice zircon being calculated based on this sample's U-Th-Pb age (Fig. 2c). This observation suggests that the Plešovice zircon has an accumulated level of radiation damage that excludes any major thermal event after magmatic growth and closure of the U-Th-Pb system (for details see Sláma et al., 2008).

\section{Samples and experimental techniques}

Xenocrysts were extracted by conventional mechanical separation from the heavy mineral fractions of crushed kimberlite material that was sampled in near-surface outcrops. Zircon grains were embedded in araldite epoxy, oriented roughly along their crystallographic c-axes, and ground and polished to about one half of their thicknesses, to expose their internal textures. These sample mounts were first imaged in reflected light under an optical microscope and then subjected to Raman microprobe analysis. After being carbon-coated, samples were subjected to BSE (back-scattered electrons) imaging and chemical analysis using EPMA (electron probe micro-analyser). Isotopic analyses by SHRIMP (Sensitive High mass Resolution Ion MicroProbe) were done after removal of the surficial carbon layer and coating with gold. After gentle re-polishing to remove the shallow SHRIMP analysis pits (depths of ca. 0.7-1.1 $\mu \mathrm{m}$; cf. Nasdala et al., 1998), some samples were attached to a glass slide, and doubly polished thin sections were produced for transmitted-light optical microscopy.

The degree of radiation damage accumulated by zircon samples was first assessed from the birefringence observed in cross-polarised transmitted light (Chakoumakos et al., 1987; Sahama, 1981). Second, it was estimated quantitatively from the Raman-band broadening (Nasdala et al., 1995, 2001). Raman spectra were obtained by means of a Horiba LabRam-HR 800 system. This system was equipped with an Olympus BX41 optical microscope, a diffraction grating with 1800 grooves $/ \mathrm{mm}$, and a Peltier-cooled charge-coupled device (CCD) detector. Spectra were excited using He-Ne $632.8 \mathrm{~nm}$ emission ( $8 \mathrm{~mW}$ at the sample surface). The laser beam was focused at the sample surface using a $100 \times$ objective (numerical aperture 0.9 ). With the system operated in the confocal mode, the lateral resolution was $\sim 1 \mu \mathrm{m}$. The volume resolution is assessed better than $5 \mu \mathrm{m}^{3}$ (compare Markwort et al., 1995). The spectral resolution was $\sim 0.8 \mathrm{~cm}^{-1}$. A minimum of three replicate measurements per sampling point were done to check for potential sample heterogeneity on a scale of within SHRIMP spots and to improve the reliability of fit results. Spectra were subjected to background correction and fitting was done assuming Lorentzian-Gaussian band shapes. Real 


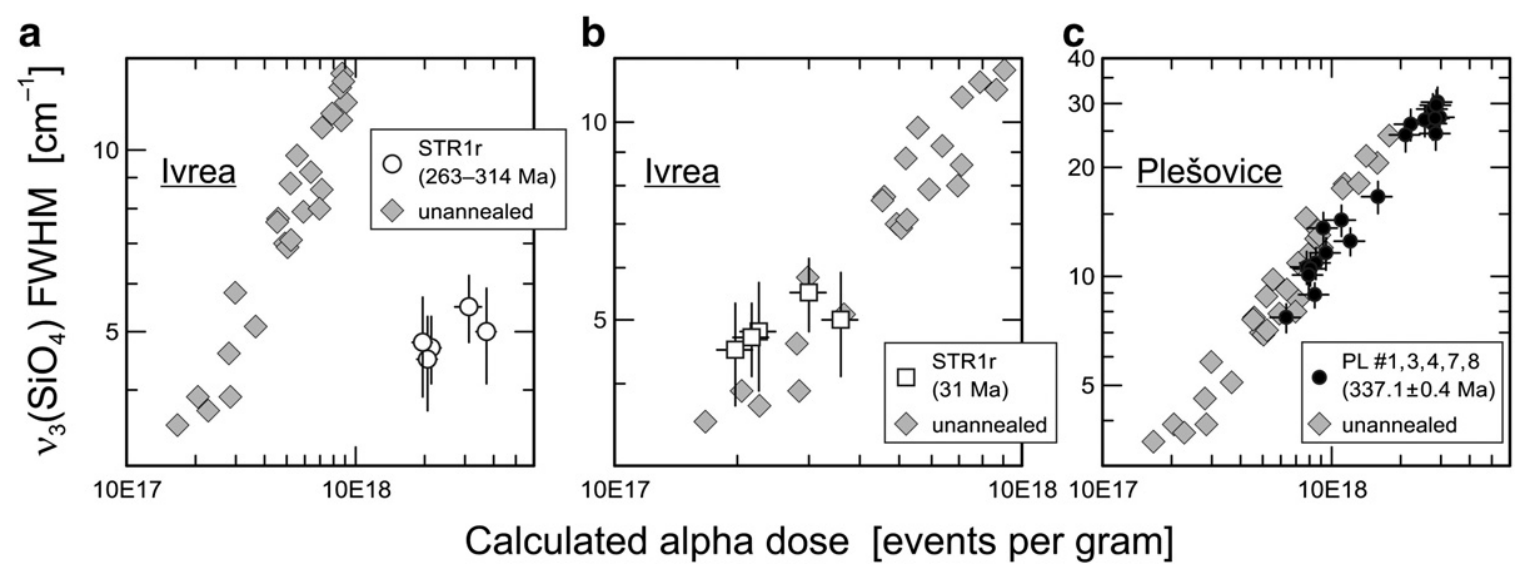

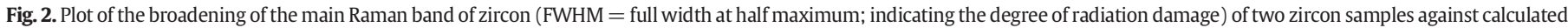

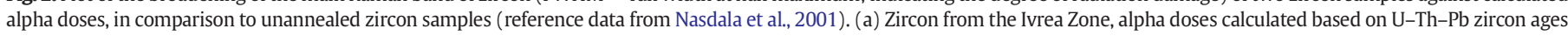

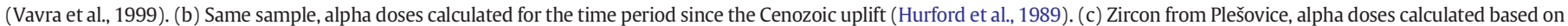
U-Th-Pb age (Sláma et al., 2008).

FWHM values were calculated by correcting measured FWHMs for the apparatus function of the Raman instrument (Dijkman and van der Maas, 1976; Váczi, 2013). The wavenumber accuracy was better than $0.5 \mathrm{~cm}^{-1}$, and total uncertainties of corrected FWHMs (i.e. including uncertainties due to micrometre-scale heterogeneity) are assessed to be smaller than $10 \%$.

The general chemical composition of the zircon samples was determined by means of a JEOL 8900 RL electron microprobe. The electron beam was focused to a $2 \mu \mathrm{m}$ spot. The accelerating voltage was $20 \mathrm{kV}$ and the beam current was $100 \mathrm{nA}$. The usual metal, oxide, and mineral standards were used, including $\mathrm{ZrSiO}_{4}$ for $\mathrm{Zr}$ and $\mathrm{Si}$, synthetic $\mathrm{HfSiO}_{4}$ for $\mathrm{Hf}$, synthetic $\mathrm{ThSiO}_{4}$ for Th, and synthetic $\mathrm{UO}_{2}$ for U. Counting times were varied between $15 \mathrm{~s}$ (peak) and $2 \times 5 \mathrm{~s}$ (lower and upper backgrounds) for the $\mathrm{K} \alpha$ line of $\mathrm{Si}$, and $300 \mathrm{~s}$ (peak) and $2 \times 150 \mathrm{~s}$ (backgrounds) for the $M \alpha$ lines of $U$ and Th. Data were reduced using the CITZAF routine in the JEOL software, which is based on the $\Phi(\rho Z)$ correction method (Armstrong, 1991, 1995).

Analyses of $\mathrm{U}$ and $\mathrm{Th}$ concentrations and the $\mathrm{Pb}$ isotopic composition were made on a SHRIMP II at Curtin University of Technology, Perth. A primary, mass-filtered $\left(\mathrm{O}_{2}\right)^{-}$beam with $\sim 1 \mathrm{nA}$ current was focused to a $~ 10 \mu \mathrm{m}$ spot to sputter the sample surface. Data for each spot were collected in sets of eight scans through the mass range of $\mathrm{Zr}_{2} \mathrm{O}^{+},{ }^{204} \mathrm{~Pb}^{+}$, background, ${ }^{206} \mathrm{~Pb}^{+},{ }^{207} \mathrm{~Pb}^{+},{ }^{208} \mathrm{~Pb}^{+},{ }^{238} \mathrm{U}^{+},{ }^{248} \mathrm{ThO}^{+}$, and ${ }^{254} \mathrm{UO}^{+}$. The mass resolution, $\mathrm{M} / \Delta \mathrm{M}$, was better than 5000 . For more experimental details see De Laeter and Kennedy (1998). Results were calibrated against M257, a 561.3 Ma old reference zircon (Nasdala et al., 2008). Common $\mathrm{Pb}$ was assumed to have a Broken Hill $\mathrm{Pb}$ composition and corrected for using the ${ }^{204} \mathrm{~Pb}$ method (Compston et al., 1984). The Excel-based programme Squid (Ludwig, 2002) was used for data processing. Data were plotted using the Isoplot programme (Ludwig, 2003).

\section{Results and discussion}

\subsection{Internal textures}

Zircon xenocrysts from both the Ary-Mastakh and the Kuoika fields have predominantly medium brown to yellowish brown (rarely reddish to pinkish brown) colours, and elongated to short-prismatic shapes that often appear rounded. Their sizes range from below $50 \mu \mathrm{m}$ to occasionally several hundred micrometres in length. The internal textures show quite some diversity, ranging from more or less uniform growth zoning (Fig. 3a, c) to complex resorption/overgrowth and alteration patterns (Fig. 3g). Many of the grains contain an inherited component, either small euhedral cores (Fig. 3b, c) or irregularly shaped regions with discordantly cut zoning (Fig. 3f, g). The inherited cores or interior regions themselves may show complex zoning (Fig. 3b, inset; g). Crusts or overgrowth rims of $\mathrm{ZrO}_{2}$, which typically form as a result of zircon alteration and decomposition in the kimberlite melt (Page et al., 2007; Robles-Cruz et al., 2012), were not observed in the present study.

Interference colours observed in cross-polarised transmitted light show remarkable scatter. Some interior regions yield "fresh" 3rd order interference colours whereas others appear isotropic (both can be seen in Fig. 3g). This indicates that the structural state of samples is characterised by strong internal diversity, ranging from mildly radiation-damaged to metamict (i.e. amorphised; Chakoumakos et al., 1987; Morgan and Auer, 1941; Sahama, 1981). Strong differences in the degree of radiation damage among zones and interior regions are also indicated by common fractures in the less damaged zones and regions (Fig. 3e-g). Fractures are typically oriented more or less perpendicular to zone boundaries; they are caused by strongly differential damage-induced volume expansion (Chakoumakos et al., 1987; Lee and Tromp, 1995; Nasdala et al., 2010; Smith et al., 1991). Interference colours show inverse correlation with BSE intensities (with the exception of the very low BSE discussed below). Interior regions and zones with lowered interference colours (and hence elevated degrees of radiation damage) show higher BSE intensity, and vice versa (Fig. 3d, g). This reconfirms again that the electron back-scatter coefficient of zircon is predominantly controlled by this mineral's structural state (Nasdala et al., 2006), whereas BSE Z-contrast caused by chemical variations is mostly insignificant in the case of natural zircon. The latter was shown experimentally by Nasdala et al. (2006) who found that (i) annealed halves of cut zircon crystals are much lower in BSE than their unannealed, chemically equivalent counterparts, and (ii) the BSE intensity of zircon correlates with the degree of radiation damage measured by Raman spectroscopy.

Another remarkable textural feature is the minor presence of interior regions with extremely low intensities in BSE images (compare Kempe et al., 2000; Pointer et al., 1988; Smith et al., 1991). This phenomenon is a reliable indicator of secondary alteration of zircon, caused by sub-micrometre porosity of the altered material and possibly the presence of water in pores (Nasdala et al., 2009; Sorbier et al., 2004). In the zircon samples studied here, such alteration patches are mostly small in size and typically occur within more radiation-damaged zones, near the ends of fractures that emanate from less radiationdamaged zones (Fig. 3e, g). Obviously less-damaged zones resisted the alteration (cf. Krogh and Davis, 1974; Medenbach, 1976). Fractures in the less-damaged zones evidently served as pathways for alteration fluids which then attacked and altered the neighbouring, more damaged areas (see BSE images in Fig. 3e, g; compare Lumpkin, 2001; 

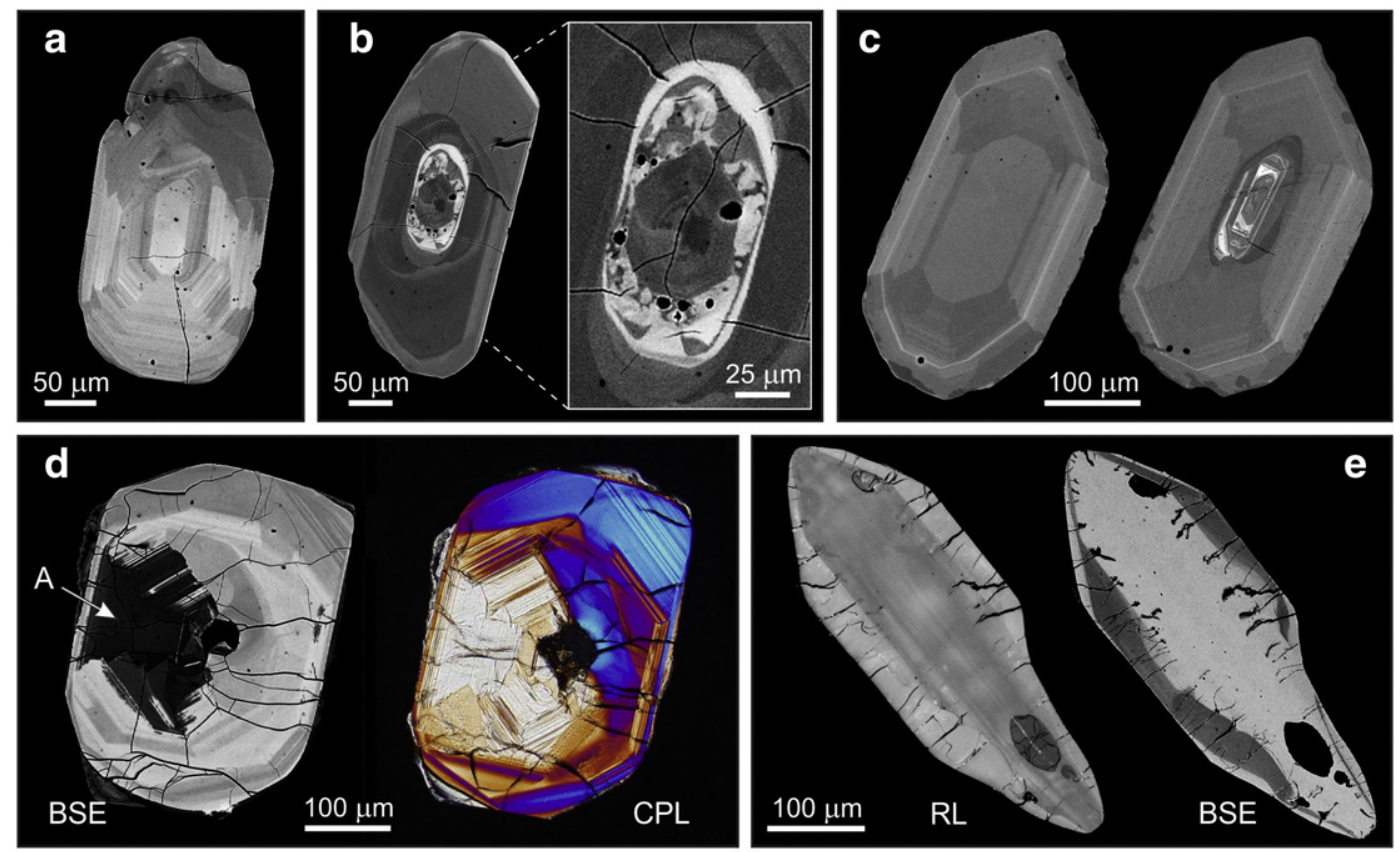

e
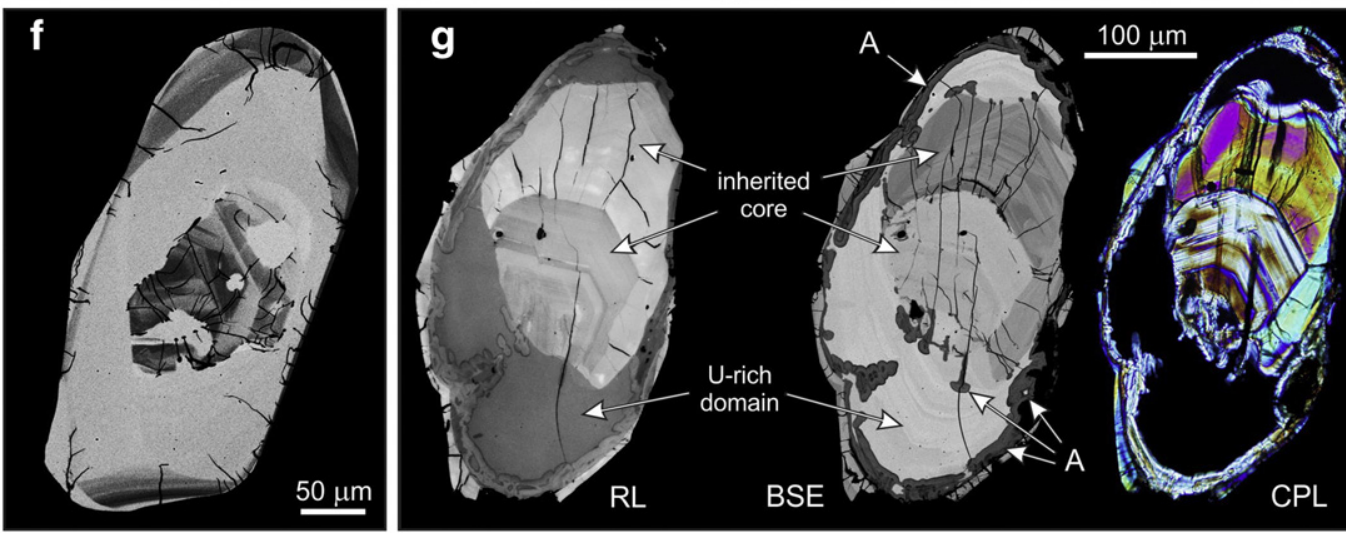

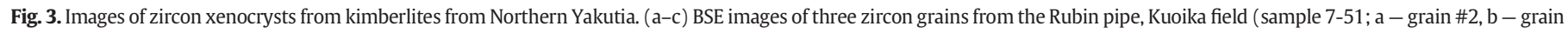

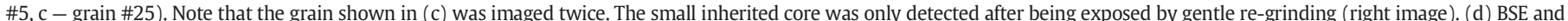

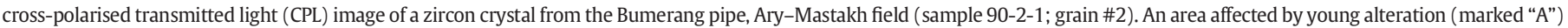

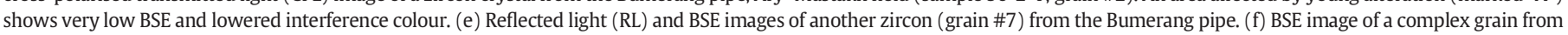

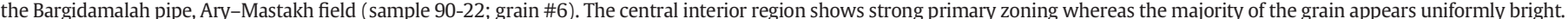

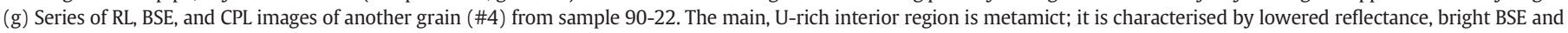

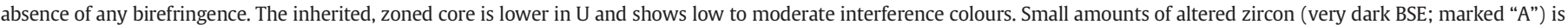
observed near the rim of the grain and at the ends of large internal fractures.

Nasdala et al., 2010). In contrast, narrow near-surface alteration rims (Fig. $3 g$ ) or large alteration patches were observed only rarely (Fig. 3d).

\subsection{Chemical compositions}

Results of chemical analyses are presented in Table 1. Except for the alteration patches, zircon grains have rather "regular" chemical compositions. Hafnium ( $\mathrm{HfO}_{2}$ 0.73-1.34 wt.\%) and uranium are the only two major non-formula constituents. Uranium concentrations are mostly several hundreds of ppm by weight or even less. Only some high-BSE interior regions contain elevated uranium with $\mathrm{UO}_{2}$ up to 0.43 wt.\% (Table 1). The partially high $U$ content of unaltered zircon supports its xenocrystic origin, as kimberlite zircon typically shows low U concentrations of below 100 ppm (e.g. Belousova et al., 1998; Haggerty et al., 1983; Spetsius et al., 2002; Valley et al., 1998; Zartmann and Richardson, 2005).

Altered areas, in contrast, show elevated concentrations of $\mathrm{Ca}$ and $\mathrm{Fe}$, with up to several wt.\% oxides. Note that these two elements are typically excluded during primary zircon growth and incorporated in low-temperature hydrothermal alteration processes (Geisler et al., 2003; Pérez-Soba et al., 2007; Törnroos, 1985). The analytical totals of altered areas are clearly deficient (93.1 and $94.9 \mathrm{wt} . \%$, respectively, for the two analyses in altered areas listed in Table 1). The analytical EPMA shortfall may be assigned to the porous sub-micrometre texture of altered material (Nasdala et al., 2009; Putnis, 2002). Such porosity first causes charge trapping and energy losses at interfaces (Sorbier et al., 2004). Second, pores may in addition host chemical species that are not analysed in the EPMA, especially water (Geisler et al., 2003; Johan and Johan, 2005; Smith et al., 1991; Törnroos, 1985; Utsunomiya et al., 2007).

\subsection{U-Th-Pb geochronology}

Results of $\mathrm{U}-\mathrm{Th}-\mathrm{Pb}$ analyses are listed in Table 2, and selected Concordia plots are presented in Fig. 4. Some of the analyses with high U content show minor reverse discordance (up to $-9 \%$; cf. Table 2 ), which is probably an analytical artefact assigned to matrix effects that 
Table 1

Results of EPMA chemical analyses (wt.\%).

\begin{tabular}{|c|c|c|c|c|c|c|c|c|c|c|c|c|c|}
\hline Grain & Interior region & $\mathrm{Al}_{2} \mathrm{O}_{3}$ & $\mathrm{SiO}_{2}$ & $\mathrm{CaO}$ & $\mathrm{FeO}$ & $\mathrm{Y}_{2} \mathrm{O}_{3}$ & $\mathrm{ZrO}_{2}$ & $\mathrm{Yb}_{2} \mathrm{O}_{3}$ & $\mathrm{HfO}_{2}$ & $\mathrm{PbO}$ & $\mathrm{ThO}_{2}$ & $\mathrm{UO}_{2}$ & Total \\
\hline \multicolumn{14}{|c|}{ Xenocrysts from pipe Ruby, Kuoika field } \\
\hline $7-51 \# 2$ & High BSE & (bdl) & 32.8 & (bdl) & (bdl) & 0.14 & 65.9 & (bdl) & 0.97 & (bdl) & 0.04 & 0.04 & 100.0 \\
\hline 7-51 \#2 & Intermediate BSE & (bdl) & 32.5 & (bdl) & (bdl) & (bdl) & 66.1 & (bdl) & 1.08 & (bdl) & (bdl) & 0.03 & 99.8 \\
\hline $7-51 \# 2$ & Low BSE & (bdl) & 32.9 & (bdl) & (bdl) & (bdl) & 65.8 & (bdl) & 1.03 & 0.04 & (bdl) & (bdl) & 100.0 \\
\hline 7-51 \#5 & Bulk & (bdl) & 32.5 & (bdl) & (bdl) & (bdl) & 65.9 & (bdl) & 1.14 & (bdl) & (bdl) & 0.03 & 99.8 \\
\hline 7-51 \#5 & Core & (bdl) & 32.7 & (bdl) & (bdl) & 0.09 & 65.7 & (bdl) & 1.23 & (bdl) & (bdl) & 0.07 & 100.0 \\
\hline 7-51 \#5 & Core, high BSE & (bdl) & 32.8 & (bdl) & (bdl) & 0.12 & 65.6 & (bdl) & 1.10 & 0.04 & (bdl) & 0.14 & 99.9 \\
\hline 7-51 \#8 & & (bdl) & 32.8 & (bdl) & (bdl) & (bdl) & 66.2 & (bdl) & 1.13 & (bdl) & (bdl) & 0.02 & 100.3 \\
\hline 7-51 \#11 & & (bdl) & 32.7 & (bdl) & (bdl) & (bdl) & 65.7 & (bdl) & 1.34 & (bdl) & (bdl) & 0.07 & 100.0 \\
\hline 7-51 \#25 & & (bdl) & 32.7 & (bdl) & (bdl) & 0.13 & 66.3 & (bdl) & 0.73 & (bdl) & (bdl) & (bdl) & 100.0 \\
\hline \multicolumn{14}{|c|}{ Xenocrysts from pipe Bumerang, Ary-Mastakh field } \\
\hline $90-2-1 \# 2$ & Bulk & (bdl) & 32.7 & (bdl) & (bdl) & (bdl) & 65.0 & (bdl) & 1.01 & (bdl) & (bdl) & (bdl) & 98.8 \\
\hline $90-2-1 \# 2$ & Altered area & (bdl) & 29.8 & 3.60 & 0.95 & 0.12 & 57.5 & (bdl) & 0.92 & (bdl) & 0.03 & 0.07 & 93.1 \\
\hline $90-2-1 \# 7$ & Central region & (bdl) & 32.5 & (bdl) & (bdl) & 0.10 & 65.8 & (bdl) & 1.07 & 0.03 & (bdl) & 0.08 & 99.8 \\
\hline $90-2-1$ \#7 & Rim & 0.04 & 32.6 & (bdl) & 0.14 & (bdl) & 65.5 & (bdl) & 1.11 & (bdl) & (bdl) & (bdl) & 99.6 \\
\hline $90-2-1$ \#8 & High BSE & (bdl) & 32.8 & (bdl) & (bdl) & (bdl) & 65.6 & (bdl) & 0.96 & (bdl) & (bdl) & 0.06 & 99.7 \\
\hline $90-2-1$ \#8 & Low BSE & (bdl) & 32.7 & (bdl) & (bdl) & (bdl) & 65.7 & (bdl) & 1.07 & (bdl) & (bdl) & 0.02 & 99.6 \\
\hline $90-2-1$ \#9 & & (bdl) & 32.9 & (bdl) & (bdl) & (bdl) & 65.9 & (bdl) & 0.97 & (bdl) & (bdl) & 0.03 & 99.9 \\
\hline $90-2-1$ \#10 & & (bdl) & 32.8 & (bdl) & (bdl) & (bdl) & 66.2 & (bdl) & 1.03 & (bdl) & (bdl) & (bdl) & 100.1 \\
\hline \multicolumn{14}{|c|}{ Xenocrysts from pipe Bargidamalah, Ary-Mastakh field } \\
\hline $90-22 \# 2$ & & (bdl) & 32.7 & (bdl) & (bdl) & (bdl) & 66.3 & (bdl) & 0.89 & (bdl) & (bdl) & (bdl) & 100.1 \\
\hline $90-22 \# 3$ & & (bdl) & 32.8 & (bdl) & (bdl) & (bdl) & 66.2 & (bdl) & 0.84 & (bdl) & (bdl) & 0.03 & 99.9 \\
\hline $90-22 \# 4$ & Core, high BSE & (bdl) & 32.7 & (bdl) & (bdl) & 0.17 & 66.0 & 0.11 & 1.03 & 0.06 & 0.04 & 0.06 & 100.4 \\
\hline $90-22 \# 4$ & Core, low BSE & (bdl) & 32.6 & (bdl) & (bdl) & (bdl) & 66.6 & (bdl) & 1.09 & (bdl) & (bdl) & (bdl) & 100.3 \\
\hline $90-22 \# 4$ & Bulk & (bdl) & 32.4 & (bdl) & (bdl) & 0.19 & 65.5 & 0.14 & 1.23 & 0.30 & (bdl) & 0.43 & 100.3 \\
\hline $90-22 \# 4$ & Alteration rim & (bdl) & 29.5 & 0.85 & 3.51 & 0.09 & 59.4 & (bdl) & 1.06 & 0.03 & (bdl) & 0.14 & 94.9 \\
\hline $90-22 \# 5$ & & (bdl) & 32.7 & (bdl) & (bdl) & (bdl) & 66.3 & (bdl) & 0.89 & (bdl) & (bdl) & (bdl) & 100.1 \\
\hline $90-22 \# 6$ & High BSE & (bdl) & 32.4 & (bdl) & (bdl) & (bdl) & 66.0 & (bdl) & 1.13 & (bdl) & (bdl) & 0.07 & 99.7 \\
\hline $90-22$ \#6 & Low BSE & (bdl) & 32.6 & (bdl) & (bdl) & (bdl) & 66.4 & (bdl) & 1.13 & (bdl) & (bdl) & 0.02 & 100.2 \\
\hline Detection limit ${ }^{a}$ & & 0.04 & 0.1 & 0.04 & 0.08 & 0.08 & 0.1 & 0.11 & 0.18 & 0.03 & 0.03 & 0.02 & - \\
\hline
\end{tabular}

$\mathrm{bdl}=$ not detected, or below the detection limit quoted in the bottom row.

a Average detection limit (wt.\% oxide; $2 \sigma$ error by counting statistics of the background signal).

commonly occur in SIMS analyses of high-U zircon (for instance see McLaren et al., 1994).

The U-Th-Pb ages determined are predominantly Paleoproterozoic, with individual ${ }^{207} \mathrm{~Pb} /{ }^{206} \mathrm{~Pb}$ age values between $2078 \pm 31$ and $1843 \pm$ $98 \mathrm{Ma}$ (Table 2; Fig. 4a, b). These results seem to concur well with Paleoproterozoic ages determined for collision-related metamorphism and mafic magmatism events within the Anabar province (Rosen et al., 2006). They are assigned to multiple collision stages of accreting independent microcontinents (Rosen et al., 2006).

The ancient microcontinents (compare Rosen, 2002; Rosen et al., 2005; and references therein) are perhaps represented by the Siderian ${ }^{207} \mathrm{~Pb} /{ }^{206} \mathrm{~Pb}$ age of $2389 \pm 107 \mathrm{Ma}$ that was determined for grain $7-51$ \#25 (Ruby pipe, Kuoika; Fig. 3a), and the Mesoarchaean ${ }^{207} \mathrm{~Pb} /{ }^{206} \mathrm{~Pb}$ age of $2832 \pm 12$ Ma determined for the U-rich, bright-BSE domain of grain 90-22 \#4 (Bargidamalah pipe, Ary-Mastakh; Figs. 3g, 4c). For instance, the age of the former seems to concur very well with the $\sim 2.4 \mathrm{Ga}$ age of the Birehtinsk granite-greenstone terrane (Rosen, 2003). The core of grain $90-22$ \#4 yielded a Paleoarchean ${ }^{207} \mathrm{~Pb} /{ }^{206} \mathrm{~Pb}$ age of $3569 \pm 33 \mathrm{Ma}$ (Fig. 4c), which is assigned to an inherited component of unknown primary origin.

Note, however, that the present study was not focused on primary ages of zircon xenocrysts; for such kind of petrogenetic study a much higher number of grains needs to be analysed (compare Batumike et al., 2007; Donatti-Filho et al., 2013; Zheng et al., 2009). Nevertheless our results indicate a non-uniform provenance; zircon xenocrysts obviously were derived from several source rocks. This conclusion is also supported by the diversity of internal textures (Fig. 3), which we interpret to reflect different formation and post-growth histories of the different source rocks.

All U-Th-Pb ages clearly predate the Mesozoic kimberlite formation. This supports again the assignment of zircon grains as xenocrysts. The majority of ages determined are concordant or only slightly discordant. There is consequently no indication of significant $\mathrm{Pb}$ loss from zircon xenocrysts during kimberlite ascent. This is in accordance with earlier findings that the $\mathrm{U}-\mathrm{Th}-\mathrm{Pb}$ system in zircon xenocrysts - in contrast to the (U-Th)/He system - often remains unaffected during the short kimberlite ascent and emplacement (McInnes et al., 2009; Vladykin and Lepekhina, 2009). Possible Pb loss during kimberlite ascent (indicated by lower intercepts that concur within errors with kimberlite eruption ages) has for instance been discussed by Zheng et al. (2009) for zircon xenocrysts from kimberlites in the North China Craton. In the present study, strong $\mathrm{U}-\mathrm{Pb}$ discordance was found only in one case (altered area in grain 90-2-1 \#2; Fig. 3d). We assign this observation (Fig. 4b) to recent $\mathrm{Pb}$ loss that was most probably caused by near-surface weathering.

\subsection{Estimation of the radiation damage}

The $v_{3}\left(\mathrm{SiO}_{4}\right)$ Raman band of zircon (i.e. crystalline $\left.\mathrm{ZrSiO}_{4}\right)$ disappears entirely when the metamictisation process is completed and amorphous $\mathrm{ZrSiO}_{4}$ has formed (Nasdala et al., 2001). The latter was found for the high-BSE domain of grain 90-22 \#4, which is in agreement with the observations of strongly lowered reflectivity and optical isotropy of this interior region (Fig. 3g).

All other zircon micro-areas studied were found to be incompletely radiation-damaged. Mild damage, indicated by small Raman-band FWHMs ( $<5 \mathrm{~cm}^{-1}$; Table 2), was for instance detected in grain 7-51 \#25 (Fig. 3c), the low-BSE zone of grain 7-51 \#2 (Fig. 3a), and grain 90-22 \#2 (not shown). Such grains, or zones within grains, typically show low BSE (and high CL) intensity, and high interference colours. Strong radiation damage, indicated by FWHMs exceeding $20 \mathrm{~cm}^{-1}$ (Table 2), was determined for instance for the central interior region of grain 90-2-1 \#7 (Fig. 3e), the central, high-BSE region of the core of grain 90-22 \#4 (Fig. $3 \mathrm{~g}$ ) and also for the large alteration patch in grain 90-2-1 \#2 (Fig. 3d). Strongly damaged grains or interior regions are 


\begin{tabular}{|c|c|c|c|c|c|c|c|c|c|c|c|c|c|c|}
\hline \multicolumn{2}{|c|}{ Measurement } & \multicolumn{10}{|c|}{ SHRIMP ion microprobe results } & \multicolumn{2}{|l|}{$\alpha$ dose $^{a}$} & \multirow{2}{*}{$\frac{\text { Raman }}{\text { FWHM }^{\mathrm{d}}\left(\mathrm{cm}^{-1}\right.}$} \\
\hline Grain & Interior region & $\overline{\mathrm{U}(\mathrm{ppm})}$ & Th (ppm) & $\mathrm{Th} / \mathrm{U}$ & f $206^{\mathrm{b}}(\%)$ & ${ }^{206} \mathrm{~Pb} /{ }^{238} \mathrm{U}$ & ${ }^{206} \mathrm{~Pb} /{ }^{238} \mathrm{U}$ age $(\mathrm{Ma})$ & ${ }^{207} \mathrm{~Pb} /{ }^{235} \mathrm{U}$ & ${ }^{207} \mathrm{~Pb} /{ }^{206} \mathrm{~Pb}$ & ${ }^{207} \mathrm{~Pb} /{ }^{206} \mathrm{~Pb}$ age $(\mathrm{Ma})$ & $\overline{\text { Disc. }^{c}(\%)}$ & $\mathrm{U}-\mathrm{Pb}$ age & $\overline{\text { Kimberlite age }}$ & \\
\hline \multicolumn{15}{|c|}{ Xenocrysts from pipe Ruby, Kuoika field } \\
\hline 7-51 \#2 & High BSE & 406 & 353 & 0.86 & 0.09 & $0.0897 \pm 0.0025$ & $554 \pm 15$ & $0.721 \pm 0.023$ & $0.0583 \pm 0.0009$ & $538 \pm 34$ & -3 & 0.91 & 0.26 & 6.9 \\
\hline 7-51 \#2 & Intermediate BSE & 224 & 161 & 0.72 & 0.24 & $0.0894 \pm 0.0022$ & $552 \pm 13$ & $0.714 \pm 0.031$ & $0.0580 \pm 0.0021$ & $526 \pm 79$ & -5 & 0.49 & 0.14 & 4.8 \\
\hline $7-51 \# 2$ & Low BSE & 80 & 33 & 0.41 & 0.00 & $0.0837 \pm 0.0028$ & $518 \pm 17$ & $0.698 \pm 0.030$ & $0.0604 \pm 0.0016$ & $617 \pm 57$ & +17 & 0.16 & 0.05 & 2.7 \\
\hline 7-51 \#5 & Bulk & 222 & 82 & 0.37 & 0.10 & $0.3600 \pm 0.0089$ & $1982 \pm 42$ & $6.25 \pm 0.16$ & $0.1258 \pm 0.0008$ & $2073 \pm 12$ & +3 & 1.9 & 0.13 & 7.9 \\
\hline 7-51 \#5 & Bulk & 162 & 55 & 0.34 & 0.00 & $0.3548 \pm 0.0093$ & $1957 \pm 44$ & $5.86 \pm 0.19$ & $0.1199 \pm 0.0024$ & $1951 \pm 36$ & -0 & 1.4 & 0.09 & 8.2 \\
\hline $7-51 \# 5$ & Bulk & 329 & 123 & 0.38 & 0.04 & $0.3441 \pm 0.0077$ & $1906 \pm 37$ & $5.56 \pm 0.13$ & $0.1173 \pm 0.0006$ & $1911 \pm 10$ & +0 & 2.8 & 0.19 & 10.8 \\
\hline $7-51 \# 5$ & Core & 658 & 56 & 0.09 & 0.02 & $0.3751 \pm 0.0076$ & $2053 \pm 36$ & $6.32 \pm 0.13$ & $0.1221 \pm 0.0007$ & $1984 \pm 11$ & -4 & 5.2 & 0.35 & (n.a.) \\
\hline $7-51 \# 5$ & Core, high BSE & 1574 & 16 & 0.01 & 0.00 & $0.3576 \pm 0.0067$ & $1971 \pm 32$ & $5.86 \pm 0.11$ & $0.1189 \pm 0.0008$ & $1936 \pm 4$ & -2 & 12.4 & 0.83 & (n.a.) \\
\hline $7-51 \# 8$ & & 207 & 51 & 0.25 & -0.02 & $0.3567 \pm 0.0091$ & $1966 \pm 43$ & $5.82 \pm 0.15$ & $0.1184 \pm 0.0008$ & $1929 \pm 13$ & -2 & 1.7 & 0.12 & 10.2 \\
\hline 7-51 \#8 & & 88 & 30 & 0.34 & 0.05 & $0.3392 \pm 0.0111$ & $1883 \pm 53$ & $5.35 \pm 0.19$ & $0.1144 \pm 0.0013$ & $1868 \pm 20$ & -1 & 0.74 & 0.05 & 6.1 \\
\hline 7-51 \#11 & & 579 & 55 & 0.09 & 0.00 & $0.3528 \pm 0.0148$ & $1948 \pm 70$ & $5.96 \pm 0.26$ & $0.1226 \pm 0.0008$ & $1991 \pm 25$ & +2 & 4.6 & 0.31 & 13.0 \\
\hline 7-51 \#25 & & 155 & 119 & 0.77 & 0.18 & $0.4383 \pm 0.0123$ & $2343 \pm 55$ & $9.60 \pm 0.29$ & $0.1588 \pm 0.0018$ & $2439 \pm 19$ & +5 & 1.4 & 0.10 & 3.4 \\
\hline 7-51 \#25 & & 50 & 50 & 0.99 & -0.09 & $0.4731 \pm 0.0191$ & $2497 \pm 84$ & $11.26 \pm 0.49$ & $0.1727 \pm 0.0028$ & $2580 \pm 27$ & +4 & 0.47 & 0.03 & 2.7 \\
\hline 7-51 \#25 & & 20 & 12 & 0.60 & 0.44 & $0.4309 \pm 0.0285$ & $2310 \pm 129$ & $9.08 \pm 0.64$ & $0.1527 \pm 0.0035$ & $2373 \pm 39$ & +3 & 0.18 & 0.01 & 2.6 \\
\hline \multicolumn{15}{|c|}{ Xenocrysts from pipe Bumerang, Ary-Mastakh field } \\
\hline $90-2-1 \# 2$ & Bulk & 137 & 37 & 0.27 & 0.06 & $0.3346 \pm 0.0095$ & $1860 \pm 46$ & $5.70 \pm 0.17$ & $0.1235 \pm 0.0010$ & $2003 \pm 15$ & +8 & 1.1 & 0.09 & 11.5 \\
\hline $90-2-1$ \#2 & Altered area & 545 & 204 & 0.38 & 4.67 & $0.1431 \pm 0.0030$ & $862 \pm 17$ & $2.48 \pm 0.07$ & $0.1255 \pm 0.0021$ & $2033 \pm 30$ & +61 & 4.7 & 0.38 & 20.7 \\
\hline $90-2-1 \# 2$ & Altered area & 621 & 221 & 0.36 & 4.21 & $0.1370 \pm 0.0028$ & $828 \pm 16$ & $2.43 \pm 0.07$ & $0.1288 \pm 0.0023$ & $2078 \pm 31$ & +64 & 5.3 & 0.43 & 21.6 \\
\hline $90-2-1 \# 7$ & Central region & 882 & 284 & 0.32 & 0.02 & $0.3542 \pm 0.0069$ & $1954 \pm 33$ & $5.94 \pm 0.12$ & $0.1217 \pm 0.0004$ & $1977 \pm 5$ & +1 & 7.5 & 0.61 & 30.7 \\
\hline $90-2-1 \# 7$ & Central region & 929 & 318 & 0.34 & 0.00 & $0.3547 \pm 0.0068$ & $1957 \pm 33$ & $5.92 \pm 0.12$ & $0.1211 \pm 0.0004$ & $1969 \pm 5$ & +1 & 7.9 & 0.65 & 20.7 \\
\hline $90-2-1 \# 7$ & $\operatorname{Rim}$ & 141 & 34 & 0.24 & 0.07 & $0.3728 \pm 0.0100$ & $2043 \pm 47$ & $6.18 \pm 0.17$ & $0.1203 \pm 0.0010$ & $1957 \pm 14$ & -5 & 1.2 & 0.10 & 9.9 \\
\hline $90-2-1 \# 7$ & Rim & 135 & 35 & 0.26 & 0.11 & $0.3514 \pm 0.0098$ & $1942 \pm 47$ & $5.78 \pm 0.17$ & $0.1192 \pm 0.0010$ & $1941 \pm 16$ & -0 & 1.1 & 0.09 & 10.6 \\
\hline $90-2-1$ \#8 & High BSE & 530 & 129 & 0.24 & 0.01 & $0.3596 \pm 0.0074$ & $1980 \pm 35$ & $5.99 \pm 0.13$ & $0.1209 \pm 0.0005$ & $1966 \pm 7$ & -1 & 4.4 & 0.36 & 24.7 \\
\hline $90-2-1$ \#8 & Low BSE & 212 & 63 & 0.30 & 0.02 & $0.3485 \pm 0.0086$ & $1928 \pm 41$ & $5.78 \pm 0.15$ & $0.1202 \pm 0.0008$ & $1956 \pm 11$ & +2 & 1.8 & 0.15 & 16.6 \\
\hline 90-2-1 \#9 & & 267 & 106 & 0.40 & 1.87 & $0.3159 \pm 0.0074$ & $1770 \pm 36$ & $5.38 \pm 0.15$ & $0.1236 \pm 0.0018$ & $2005 \pm 26$ & +13 & 2.3 & 0.19 & 13.1 \\
\hline $90-2-1 \# 10$ & & 194 & 45 & 0.23 & 0.08 & $0.3515 \pm 0.0090$ & $1942 \pm 43$ & $5.94 \pm 0.16$ & $0.1226 \pm 0.0009$ & $1990 \pm 12$ & +3 & 1.6 & 0.13 & 18.9 \\
\hline \multicolumn{15}{|c|}{ Xenocrysts from pipe Bargidamalah, Ary-Mastakh field } \\
\hline $90-22 \# 2$ & & 11 & 5 & 0.50 & 0.52 & $0.3544 \pm 0.0163$ & $1956 \pm 78$ & $5.52 \pm 0.39$ & $0.1129 \pm 0.0061$ & $1843 \pm 98$ & -7 & 0.01 & 0.01 & 2.4 \\
\hline 90-22 \#3 & & 276 & 112 & 0.41 & 0.08 & $0.3478 \pm 0.0069$ & $1924 \pm 33$ & $5.73 \pm 0.12$ & $0.1195 \pm 0.0009$ & $1945 \pm 13$ & +1 & 2.3 & 0.19 & 12.3 \\
\hline $90-22 \# 3$ & & 419 & 193 & 0.46 & 0.17 & $0.3585 \pm 0.0069$ & $1975 \pm 33$ & $5.94 \pm 0.12$ & $0.1202 \pm 0.0007$ & $1955 \pm 11$ & -1 & 3.6 & 0.30 & 15.6 \\
\hline $90-22 \# 4$ & Core, high BSE & 551 & 279 & 0.51 & 0.00 & $0.7331 \pm 0.0139$ & $3545 \pm 52$ & $32.6 \pm 0.62$ & $0.3220 \pm 0.0006$ & $3575 \pm 3$ & +1 & 7.8 & 0.40 & 20.2 \\
\hline $90-22$ \#4 & Core, high BSE & 415 & 194 & 0.47 & 0.03 & $0.7090 \pm 0.0136$ & $3455 \pm 51$ & $30.5 \pm 0.60$ & $0.3119 \pm 0.0013$ & $3525 \pm 6$ & +3 & 5.9 & 0.30 & 22.7 \\
\hline $90-22 \# 4$ & Core, high BSE & 453 & 213 & 0.47 & 0.02 & $0.7207 \pm 0.0138$ & $3499 \pm 52$ & $31.9 \pm 0.61$ & $0.3208 \pm 0.0007$ & $3569 \pm 4$ & +3 & 6.4 & 0.32 & 16.4 \\
\hline $90-22 \# 4$ & Core, high BSE & 447 & 232 & 0.52 & 0.01 & $0.7090 \pm 0.0136$ & $3455 \pm 51$ & $30.8 \pm 0.60$ & $0.3146 \pm 0.0012$ & $3539 \pm 6$ & +3 & 6.4 & 0.32 & 27.9 \\
\hline $90-22 \# 4$ & Core, low BSE & 130 & 49 & 0.38 & 0.02 & $0.7681 \pm 0.0161$ & $3674 \pm 59$ & $35.1 \pm 0.82$ & $0.3313 \pm 0.0035$ & $3618 \pm 16$ & -2 & 1.8 & 0.09 & 12.0 \\
\hline $90-22 \# 4$ & Core, low BSE & 141 & 54 & 0.38 & 0.08 & $0.7846 \pm 0.0165$ & $3734 \pm 60$ & $35.1 \pm 0.75$ & $0.3247 \pm 0.0013$ & $3587 \pm 6$ & -5 & 1.9 & 0.10 & 10.1 \\
\hline $90-22 \# 4$ & High BSE & 2751 & 106 & 0.04 & 0.01 & $0.5565 \pm 0.0103$ & $2852 \pm 42$ & $15.2 \pm 0.28$ & $0.1987 \pm 0.0035$ & $2812 \pm 4$ & -2 & 36.1 & 1.8 & (Metamict) \\
\hline $90-22 \# 4$ & High BSE & 3406 & 149 & 0.04 & 0.00 & $0.5608 \pm 0.0106$ & $2870 \pm 44$ & $15.6 \pm 0.30$ & $0.2022 \pm 0.0005$ & $2840 \pm 4$ & -1 & 44.7 & 2.2 & (Metamict) \\
\hline $90-22 \# 4$ & High BSE & 3708 & 144 & 0.04 & 0.00 & $0.5735 \pm 0.0107$ & $2922 \pm 44$ & $16.0 \pm 0.30$ & $0.2023 \pm 0.0004$ & $2841 \pm 3$ & -4 & 48.7 & 2.4 & (Metamict) \\
\hline $90-22 \# 4$ & High BSE & 2103 & 78 & 0.04 & 0.00 & $0.5999 \pm 0.0111$ & $3030 \pm 45$ & $16.7 \pm 0.31$ & $0.2017 \pm 0.0006$ & $2835 \pm 5$ & -9 & 27.6 & 1.4 & (Metamict) \\
\hline 90-22 \#4 & High BSE & 3490 & 143 & 0.04 & 0.00 & $0.5719 \pm 0.0105$ & $2916 \pm 43$ & $15.9 \pm 0.29$ & $0.2011 \pm 0.0002$ & $2831 \pm 2$ & -4 & 45.8 & 2.3 & (Metamict) \\
\hline $90-22 \# 5$ & & 25 & 24 & 0.97 & 0.53 & $0.5561 \pm 0.0169$ & $2850 \pm 70$ & $16.8 \pm 0.58$ & $0.2189 \pm 0.0036$ & $2968 \pm 26$ & +5 & 0.4 & 0.02 & 5.5 \\
\hline $90-22 \# 6$ & High BSE & 772 & 74 & 0.10 & 0.06 & $0.3387 \pm 0.0066$ & $1880 \pm 32$ & $5.49 \pm 0.11$ & $0.1175 \pm 0.0007$ & $1915 \pm 11$ & +2 & 5.9 & 0.51 & 17.0 \\
\hline $90-22 \# 6$ & High BSE & 531 & 141 & 0.27 & 0.04 & $0.3379 \pm 0.0064$ & $1877 \pm 31$ & $5.37 \pm 0.11$ & $0.1153 \pm 0.0005$ & $1881 \pm 8$ & +0 & 4.2 & 0.36 & 23.0 \\
\hline $90-22 \# 6$ & Low BSE & 300 & 84 & 0.28 & 0.04 & $0.3471 \pm 0.0068$ & $1921 \pm 32$ & $5.48 \pm 0.11$ & $0.1146 \pm 0.0007$ & $1870 \pm 11$ & -3 & 2.4 & 0.21 & 19.1 \\
\hline
\end{tabular}

Isotopic ratios are corrected for common $\mathrm{Pb}\left({ }^{204} \mathrm{~Pb}\right.$ method). Isotopic ratios and ages are quoted with $1 \sigma$ uncertainties.

a Time-integrated alpha dose, calculated twice (first, assuming damage accumulation since the time of closure of the U-Th-Pb system; second, assuming damage accumulation since the time of kimberlite formation).

b $\mathrm{f} 206=$ common ${ }^{206} \mathrm{~Pb} /$ total ${ }^{206} \mathrm{~Pb}$, calculated from the observed ${ }^{204} \mathrm{~Pb}$.

${ }^{c}$ Disc. = U-Pb discordance; difference between the ${ }^{204} \mathrm{~Pb}$-corrected ${ }^{206} \mathrm{~Pb} /{ }^{238} \mathrm{U}$ and ${ }^{207} \mathrm{~Pb} / 206 \mathrm{~Pb}$ ages.

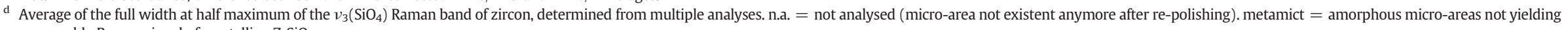
any measurable Raman signal of crystalline $\mathrm{ZrSiO}_{4}$. 
characterised by increased BSE and low (and partially anomalous) interference colours.

\subsection{Degree of damage retention}

Time-integrated alpha doses $D_{\alpha}$ of the zircon xenocrysts under investigation are listed in Table 2. These doses were calculated twice. First, they were calculated for the time period since closure of the U-Th-Pb system (for inherited cores, the age of the corresponding bulk was used). Second, doses were calculated for the time period since Mesozoic kimberlite formation (Table 2). Data pairs are plotted in Fig. 5.

Alpha doses based on $\mathrm{U}-\mathrm{Th}-\mathrm{Pb}$ ages quantify the entire radioactive self-irradiation since zircon formation (or since the hypothetical annealing of cores upon being overgrown, respectively). The corresponding FWHM- $\mathrm{D}_{\alpha}$ data pairs plot below the trend defined by data pairs for unannealed zircon (Fig. 5a, b). This indicates that zircon xenocrysts did not completely accumulate the radiation damage caused by radioactive self-irradiation since the time of their formation. This conclusion is supported by geological evidence. For instance, in a study of Neoproterozoic crustal xenoliths (ages about 2000-1960 Ma) in kimberlites from the Anabar shield, Rosen et al. (2006) found that cooling from 700 to $\sim 300{ }^{\circ} \mathrm{C}$ lasted approximately 300 m.y. On the other hand, it is well known that at temperatures exceeding $200-300{ }^{\circ} \mathrm{C}$, radiation damage is not accumulated but, in contrast, moderately radiation-damaged zircon undergoes slow structural reconstitution (e.g., Meldrum et al., 1998, 1999). Consequently, accumulation of radiation damage in zircon xenocrysts cannot have started immediately after closure of the U-Th-Pb system (roughly $600-650{ }^{\circ} \mathrm{C}$ under metamorphic conditions; Mezger and Krogstad, 1997).

The extents of mismatches of FWHM- $\mathrm{D}_{\alpha}$ data pairs observed in the present study (Fig. 4a, b) indicate that zircon xenocrysts are roughly half as radiation-damaged as corresponds to their ages. This high level of damage storage in zircon xenocrysts implies that previous host rocks must have resided at temperatures well below $300{ }^{\circ} \mathrm{C}$, for at least one half or their entire history. Assuming a geothermal gradient of roughly $25-30{ }^{\circ} \mathrm{C} / \mathrm{km}$ for the Northern Yakutian kimberlite province, this suggests that zircon xenocrysts sampled by the ascending kimberlite magmas originate from comparably shallow levels of the Earth's crust, not exceeding 10-12 km. In view of the local crustal thickness of 40$45 \mathrm{~km}$ (Suvorov et al., 2006), this indicates that the zircon xenocrysts studied here were probably not derived from lower but upper crustal rocks.

Data pairs of Raman FWHMs and alpha doses based on the kimberlite-formation ages (Fig. 5c, d), in contrast, plot above and to the left of the unannealed zircon trend. In fact, the Raman-band broadening of xenocrysts exceeds several times the band broadening of unannealed references with the same calculated alpha doses. Consequently, zircon xenocrysts are much more radiation-damaged than it would correspond to damage accumulation only since the time of kimberlite formation. Our observations hence contradict the hypothesis that high temperatures during kimberlite ascent will cause complete structural reconstitution of zircon xenocrysts, by thermal annealing of the accumulated radiation damage.

Zhang et al. (2000) have shown that $1 \mathrm{~h}$ of dry heating of moderately radiation-damaged zircon (FWHMs in the range $5-25 \mathrm{~cm}^{-1}$ ) at $800-1100{ }^{\circ} \mathrm{C}$ results in major but incomplete reconstitution. Initial annealing was observed already at temperatures as low as $500{ }^{\circ} \mathrm{C}$ by these authors. Zhang et al. (2000) demonstrated also that not only the annealing temperature but also the duration of the heat treatment has strong effects on the extent of the recovery. In an annealing study on Sri Lanka gem zircon it was found that thermal treatment of moderately damaged zircon at $600{ }^{\circ} \mathrm{C}$ ( 4 days) resulted in moderate reconstitution (C.L. Lengauer, personal communication), and heating at $1000{ }^{\circ} \mathrm{C}$ (4 days) caused major but still incomplete recovery (Mattinson et al., 2007). In view of these previous results, our present observations
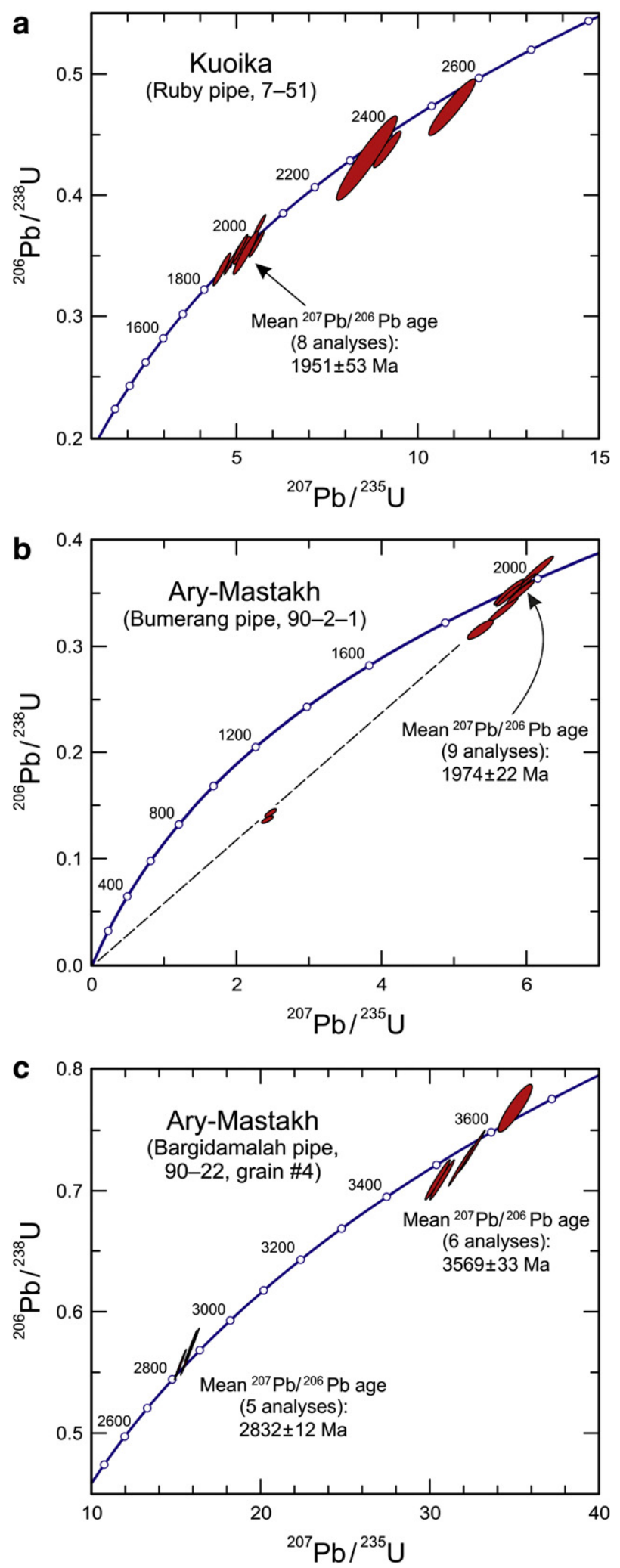

Fig. 4. Three plots showing selected results of SHRIMP U-Th-Pb analyses. Error ellipses represent $2 \sigma$ uncertainties. Strong discordance of the $\mathrm{U}-\mathrm{Th}-\mathrm{Pb}$ isotopic system was found only in one case (see middle plot).

suggest that the zircon xenocrysts under investigation cannot have experienced temperatures above $600-800{ }^{\circ} \mathrm{C}$ (with the maximum temperature depending strongly on the duration of the thermal event).

Some authors have concluded that kimberlite magma may ascend with high velocities (faster than $10 \mathrm{~m} / \mathrm{s}$ ), especially along narrow 


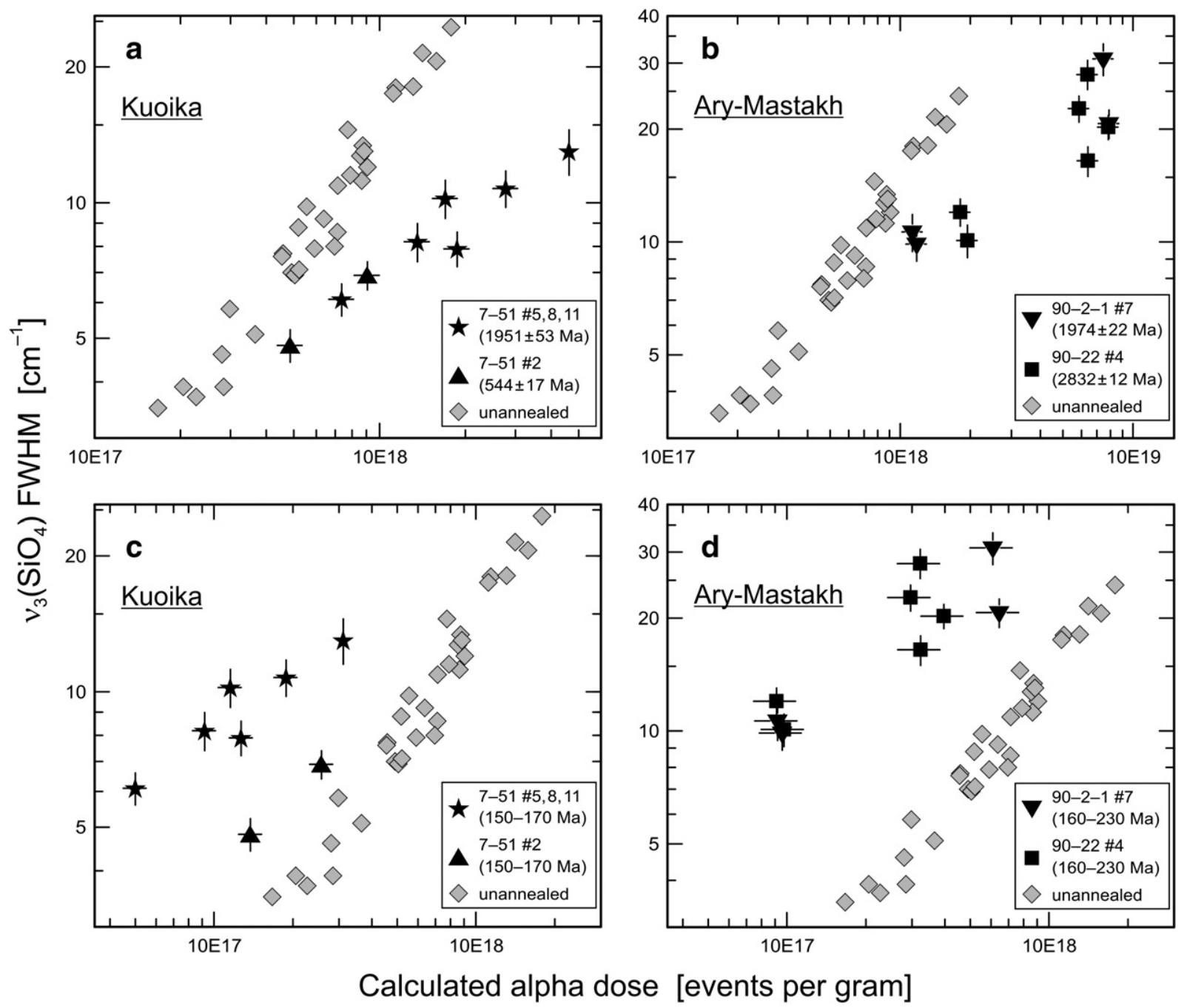

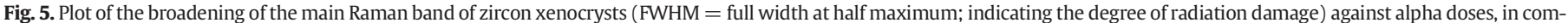

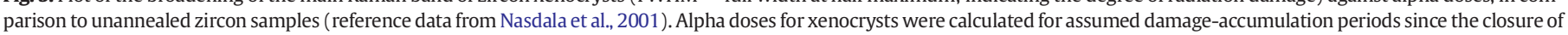

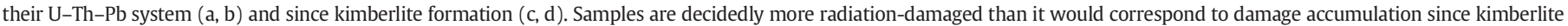
formation only.

dykes; hence rock formation would take only a few hours (Mattsson, 2012; Sparks et al., 2006; Wilson and Head, 2007). If such a timeregime should apply to the kimberlites studied here, the temperature reached by zircon crystals in the kimberlite magma cannot have exceeded $\sim 700-800{ }^{\circ} \mathrm{C}$. Alternatively, Kostrovitsky (1986) has postulated slow magma-ascent velocities on the order of $1 \mathrm{~m} / \mathrm{s}$, and slow subsequent cooling, leading to comparably slow kimberlite formation. Sparks et al. (2006) have proposed that kimberlite formation may extend over several days or even weeks in the case of large-diameter dykes. In such longer-term rock-formation processes, the temperature of zircon xenocrysts must have remained even well below $500-600{ }^{\circ} \mathrm{C}$, to facilitate major damage retention.

Another noteworthy observation is that the U-rich domain of grain 90-22 \#4 (Fig. 3g) consists solely of amorphous $\mathrm{ZrSiO}_{4}$. Alpha doses calculated for the time since kimberlite formation (1.4-2.4 $\times 10^{18}$ events/g; Table 2) would correspond merely to moderate stages of damage accumulation. Note that amorphisation requires close to $10^{19}$ alphadecay events/g (Murakami et al., 1991; Nasdala et al., 2001). It therefore seems reasonable to assume that the U-rich domain of grain 90-22 \#4 was amorphised, or at least close to amorphous, by the time of the kimberlite ascent, without having experienced major annealing. Also, it is remarkable that neither tetragonal nor monoclinic $\mathrm{ZrO}_{2}$ was not observed. It is well known that (dry) heating of amorphous $\mathrm{ZrSiO}_{4}$ in an intermediate temperature range of approximately $800-1150{ }^{\circ} \mathrm{C}$ for several hours results in chemical decomposition, that is, formation of a multitude of (crystalline) $\mathrm{ZrO}_{2}$ crystals embedded in an amorphous silica matrix (Capitani et al., 2000; Nasdala et al., 2002). This was not detected here. We may conclude again that, between being sampled by the hot, ascending kimberlite magma, and cooling near the Earth surface, zircon xenocrysts cannot have experienced temperatures in excess of $800{ }^{\circ} \mathrm{C}$.

\section{Concluding remarks}

Our results suggest that major structural reconstitution of zircon in the hot kimberlite magma, through thermal annealing of previously accumulated radiation damage, can be discounted. Notable weathering or hydrothermal overprinting following the kimberlite emplacement can also be excluded. First, in spite of the occasionally high radiation damage, the majority of the zircon appears "fresh", with only a tiny volume fraction of alteration patches (Fig. 3). Second, U-Pb discordance assigned to recent loss of radiogenic $\mathrm{Pb}$ was only observed in one case (Fig. 4b). The complex observations made in the present study suggest that sampling by the hot kimberlite magma, kimberlite ascent, and subsequent kimberlite cooling near the Earth's surface, had very minor effects on zircon composition and physical parameters. Zircon 
xenocrysts from kimberlites in the Kuoika and Ary-Mastakh fields are hence very suitable for the unbiased investigation of precursor rocks.

It is clear, however, that our results cannot be generalised. The ratio of damage retention and damage annealing experienced by zircon xenocrysts in the kimberlite magma will always depend on depth of sampling by the kimberlite magma, ascent velocity (both controlling the dwell time in the hot magma), and magma temperature. It seems worthwhile to subject future studies of zircon xenocrysts from kimberlites to a direct comparison of short-term, low-temperature effects, namely fractional structural recovery of previously accumulated radiation damage, and fractional loss of radiogenic helium.

\section{Acknowledgements}

We thank A. Wagner for sample preparation and N. Groschopf, E. Libowitzky, and M. Müller for experimental help. C.L. Lengauer and C.-Z. Liu are thanked for providing unpublished data. The SHRIMP reference zircon M257 was made available by W. Hofmeister (Institute of Gemstone Research, Idar-Oberstein and Mainz, Germany). The SHRIMP II ion microprobe used in this study is operated by a consortium consisting of Curtin University of Technology, the University of Western Australia, and the Geological Survey of Western Australia. Constructive comments by F. Corfu, an anonymous reviewer, and editor N. Eby are gratefully acknowledged. This research was supported partially by the Austrian Science Fund (FWF) through grant P24448-N19 to L.N. Co-authors S.K. and S.E. are thankful to the Russian Academy of Sciences funding through grants N 59, 151, and 27.1.

\section{References}

Armstrong, J.T., 1991. Quantitative elemental analysis of individual microparticles with electron beam instruments. In: Heinrich, K.F.J., Newbury, D.E. (Eds.), Electron Probe Quantitation. Plenum Press, New York, London, pp. 261-315.

Armstrong, J.T., 1995. CITZAF: a package of correction programs for the quantitative electron microbeam X-ray analysis of thick polished materials, thin films, and particles. Microbeam Analysis 4, 177-200.

Batumike, J.M., O'Reilly, S.Y., Griffin, W.L., Belousova, E.A., 2007. U-Pb and Hf-isotope analyses of zircon from the Kundelungu Kimberlites, D.R. Congo: implications for crustal evolution. Precambrian Research 156, 195-225.

Belousova, E.A., Griffin, W.L., Pearson, N.J., 1998. Trace element composition and cathodoluminescence properties of southern African kimberlitic zircons. Mineralogical Magazine 62, 355-366.

Buzlukova, L.V., Shatsky, V.S., Sobolev, N.V., 2004. Specific structure of the lowermost Earth's crust at the Zagadochnaya kimberlite pipe, Yakutia. Russian Geology and Geophysics 45, 992-1007.

Capitani, G.C., Leroux, H., Doukhan, J.C., Ríos, S., Zhang M., Salje, E.K.H., 2000. A TEM investigation of natural metamict zircons: structure and recovery of amorphous domains. Physics and Chemistry of Minerals 27, 545-556.

Chakoumakos, B.C., Murakami, T., Lumpkin, G.R., Ewing, R.C., 1987. Alpha-decay-induced fracturing in zircon: the transition from the crystalline to the metamict state. Science 236, 1556-1559.

Compston, W., Williams, I.S., Meyer, C., 1984. U-Pb geochronology of zircon from lunar breccia 73217 using a sensitive high mass-resolution ion microprobe. Journal of Geophysical Resources 89, 525-534.

Cowan, G.A., Adler, H.H., 1976. Variability of natural abundance of U-235. Geochimica et Cosmochimica Acta 40, 1487-1490.

Dawson, P., Hargreave, M.M., Wilkinson, G.R., 1971. The vibrational spectrum of zircon $\left(\mathrm{ZrSiO}_{4}\right)$. Journal of Physics C: Solid State Physics 4, 240-256.

De Laeter, J.R., Kennedy, A.K., 1998. A double focussing mass spectrometer for geochronology. International Journal of Mass Spectrometry and Ion Processes 178, 43-50.

Dijkman, F.G., van der Maas, J.H., 1976. Dependence of bandshape and depolarization ratio on slitwidth. Applied Spectroscopy 30, 545-546.

Donatti-Filho, J.P., Oliveira, E.P., McNaughton, N.J., 2013. Provenance of zircon xenocrysts in the Neoproterozoic Brauna Kimberlite Field, São Francisco Craton, Brazil: evidence for a thick Palaeoproterozoic lithosphere beneath the Serrinha block. Journal of South American Earth Sciences 45, 83-96.

Geisler, T., Rashwan, A.A., Rahn, M.K.W., Poller, U., Zwingmann, H., Pidgeon, R.T., Schleicher, H., Tomaschek, F., 2003. Low-temperature hydrothermal alteration of natural metamict zircon from the Eastern Desert, Egypt. Mineralogical Magazine 67, 485-508.

Griffin, W.L., Ryan, C.G., Kaminsky, F.V., O'Reilly, S.Y., Natapov, L.M., Win, T.T., Kinny, P.D., Ilupin, I.P., 1999. The Siberian lithosphere traverse: mantle terranes and the assembly of the Siberian Craton. Tectonophysics 310, 1-35.

Haggerty, S.E., Raber, E., Naeser, C.N., 1983. Fission track dating of kimberlitic zircons. Earth and Planetary Science Letters 63, 41-50.
Hurford, A.J., Flisch, M., Jäger, E., 1989. Unravelling the thermo-tectonic evolution of the Alps: a contribution from fission track analysis and mica dating. In: Coward, M.P. Dietrich, D., Park, R.G. (Eds.), Alpine tectonics. Geological Society Special Paper. 45, pp. 369-398.

Johan, Z., Johan, V., 2005. Accessory minerals of the Cínovec (Zinnwald) granite cupola Czech Republic: indicators of petrogenetic evolution. Mineralogy and Petrology 83 $113-150$.

Kempe, U, Gruner T Nasdala, L Wolf, D, 2000. Relevance of cathodoluminescence for the interpretation of $\mathrm{U}-\mathrm{Pb}$ zircon ages, with an example of an application to a study of zircons from the Saxonian Granulite Complex, Germany. In: Pagel, M. Barbin, V., Blanc, P., Ohnenstetter, D. (Eds.), Cathodoluminescence in Geosciences. Springer, Berlin, Heidelberg, New York, pp. 415-455.

Kharkiv, A.D., Zinchuk, N.N., Kryuchkov, A.I., 1998. Primary Diamond Deposits in the World (in Russian). Nedra, Moscow.

Kinny, P.D., Griffin, B.J., Heaman, L.M., Brakhfogel, F.F., Spetsius, Z.V., 1997. SHRIMP U-Pb ages of perovskite from Yakutian kimberlites. Russian Geology and Geophysics 38, 91-99.

Koreshkova, M.Y., Downes, H., Nikitina, L.P., Vladykin, N.V., Larionov, A.N., Sergeev, S.A 2009. Trace element and age characteristics of zircons in granulite xenoliths from the Udachnaya kimberlite pipe, Siberia. Precambrian Research 168, 197-212.

Kostrovitsky, S.I., 1986. Physical Conditions, Hydraulics and Kinematics of Infill of Kimberlite Pipes (in Russian). Nauka, Novosibirsk.

Kostrovitsky, S.I., Soloveva, L.V., Yakovlev, D.A., Suvorova, L.F., Sandimirova, G.P., Travin, A. V., Yudin, D.S., 2013. Kimberlites and megacrystic suite: isotope-geochemical studies. Petrology 21, 127-144

Krogh, T.E., Davis, G.L., 1974. Alteration in zircons with discordant U-Pb ages. Carnegie Institution of Washington Year Book. 73, pp. 560-567.

Lee, J.K.W., Tromp, J., 1995. Self-induced fracture generation in zircon. Journal of Geophysical Research - Solid Earth 100, 17753-17770.

Ludwig, K.R., 2002. SQUID 1.02, a user's manual. Berkeley Geochronology Center Special Publication. 2, (22 p).

Ludwig, K.R., 2003. User's manual for Isoplot 3.00: a geochronological toolkit for Microsoft Excel. Berkeley Geochronology Center Special Publication. 4, (71 p).

Lumpkin, G.R., 2001. Alpha-decay damage and aqueous durability of actinide host phases in natural systems. Journal of Nuclear Materials 289, 136-166.

Markwort, L., Kip, B., da Silva, E., Roussel, B., 1995. Raman imaging of heterogeneous polymers: a comparison of global versus point illumination. Applied Spectroscopy 49, 1411-1430.

Mattinson, J.M., Nasdala, L., Lengauer, C., Wirth, R., 2007. Inside CA-TIMS zircon analysis: the interplay among natural radiation damage, annealing, solubility, and $\mathrm{U}-\mathrm{Pb}$ isotopic systematics. AGU 2007 Fall Meeting, San Francisco, CA, U.S.A., December, 2007 Eos, Transactions American Geophysical Union 88 (52, Supplement) (Abstract V31G-06).

Mattsson, H.B., 2012. Rapid magma ascent and short eruption durations in the Lake Natron-Engaruka monogenetic volcanic field (Tanzania): a case study of the olivine melilititic Pello Hill scoria cone. Journal of Volcanology and Geothermal Research 247-248, 16-25.

McInnes, B.I.A., Evans, N.J., McDonald, B.J., Kinny, P.D., Jakimowicz, J., 2009. Zircon U-Th$\mathrm{Pb}-\mathrm{He}$ double dating of the Merlin kimberlite field, Northern Territory, Australia. Lithos 112S, 592-599.

McLaren, A.C., Fitz Gerald, J.D., Williams, I.S., 1994. The microstructure of zircon and its influence on the age determination from $\mathrm{Pb} / \mathrm{U}$ isotopic ratios measured by ion microprobe. Geochimica et Cosmochimica Acta 58, 993-1005

Medenbach, O., 1976. Geochemie der Elemente in Zirkon und ihre räumliche Verteilung eine Untersuchung mit der Elektronenstrahlmikrosonde. (Doctoral thesis) RuprechtKarls-Universität Heidelberg, Germany.

Meldrum, A., Boatner, L.A., Weber, W.J., Ewing, R.C., 1998. Radiation damage in zircon and monazite. Geochimica et Cosmochimica Acta 62, 2509-2520.

Meldrum, A., Boatner, L.A., Zinkle, S.J., Wang, S.-X., Wang, L.-M., Ewing, R.C., 1999. Effects of dose rate and temperature on the crystalline-to-metamict transformation in the $\mathrm{ABO}_{4}$ orthosilicates. Canadian Mineralogist 37, 207-221.

Mezger, K., Krogstad, E.J., 1997. Interpretation of discordant U-Pb ages: an evaluation. Journal of Metamorphic Geology 15, 127-140.

Morgan, J.H., Auer, M.L., 1941. Optical, spectrographic, and radio-activity studies of zircon. American Journal of Science 239, 305-311.

Murakami, T., Chakoumakos, B.C., Ewing, R.C., Lumpkin, G.R., Weber, W.J., 1991. Alphadecay event damage in zircon. American Mineralogist 76, 1510-1532.

Nasdala, L., Irmer, G., Wolf, D., 1995. The degree of metamictization in zircon: a Raman spectroscopic study. European Journal of Mineralogy 7, 471-478.

Nasdala, L., Pidgeon, R.T., Wolf, D., Irmer, G., 1998. Metamictization and U-Pb isotopic discordance in single zircons: a combined Raman microprobe and SHRIMP ion probe study. Mineralogy and Petrology 62, 1-27.

Nasdala, L., Wenzel, M., Vavra, G., Irmer, G., Wenzel, T., Kober, B., 2001. Metamictisation of natural zircon: accumulation versus thermal annealing of radioactivity-induced damage. Contributions to Mineralogy and Petrology 141, 125-144.

Nasdala, L., Lengauer, C.L., Hanchar, J.M., Kronz, A., Wirth, R., Blanc, P., Kennedy, A.K. Seydoux-Guillaume, A.-M., 2002. Annealing radiation damage and the recovery of cathodoluminescence. Chemical Geology 191, 121-140.

Nasdala, L., Kronz, A., Hanchar, J.M., Tichomirowa, M., Davis, D.D., Hofmeister, W., 2006 Effects of natural radiation damage on back-scattered electron images of singlecrystals of minerals. American Mineralogist 91, 1738-1746.

Nasdala, L., Hofmeister, W., Norberg, N., Mattinson, J.M., Corfu, F., Dörr, W., Kamo, S.L., Kennedy, A.K., Kronz, A., Reiners, P.W., Frei, D., Kosler, J., Wan, Y., Götze, J., Häger, T. Kröner, A., Valley, J.W., 2008. Zircon M257 - a homogeneous natural reference material for the ion microprobe U-Pb analysis of zircon. Geostandards and Geoanalytical Research 32, 247-265. 
Nasdala, L., Kronz, A., Wirth, R., Váczi, T., Pérez-Soba, C., Willner, A., Kennedy, A.K., 2009. Alteration of radiation-damaged zircon and the related phenomenon of deficient electron microprobe totals. Geochimica et Cosmochimica Acta 73, 1637-1650.

Nasdala, L., Hanchar, J.M., Rhede, D., Kennedy, A.K., Váczi, T., 2010. Retention of uranium in complexly altered zircon: an example from Bancroft, Ontario. Chemical Geology 269, 290-300

Neymark, L.A., Nemchin, A.A., Rosen, O.M., Serenko, V.P., Spetsius, Z.V., Shuleshko, I.K., 1992. Sm-Nd isotopic systems in xenoliths of lower crust from kimberlites of Yakutia. Doklady Akademii Nauk 327, 374-378.

Page, F.Z., Fu, B., Kita, N.T., Fournelle, J., Spicuzza, M.J., Schulze, D.J., Viljoen, F., Basei, M.A.S. Valley, J.W., 2007. Zircons from kimberlite: new insights from oxygen isotopes, trace elements, and Ti in zircon thermometry. Geochimica et Cosmochimica Acta 71, 3887-3903.

Pérez-Soba, C., Villaseca, C., Gonzáles del Tánago, J., Nasdala, L., 2007. The composition of zircon in the peraluminous Hercynian granites of the Spanish Central System batholith. Canadian Mineralogist 45, 509-527.

Pointer, C.M., Ashworth, J.R., Ixer, R.A., 1988. The zircon-thorite mineral group in metasomatized granite, Ririwai, Nigeria. 2. Zoning, alteration and exsolution in zircon. Mineralogy and Petrology 39, 21-37.

Putnis, A., 2002. Mineral replacement reactions: from macroscopic observations to microscopic mechanisms. Mineralogical Magazine 66, 689-708.

Robles-Cruz, S.E., Escayola, M., Jackson, S., Galí, S., Pervov, V., Watangua, M., Gonçalves, A Melgarejo, J.C., 2012. U-Pb SHRIMP geochronology of zircon from the Catoca kimberlite, Angola: implications for diamond exploration. Chemical Geology 310-311, 137-147.

Rosen, O.M., 2002. Siberian craton - a fragment of a Paleoproterozoic supercontinent. Russian Journal of Earth Sciences 4, 103-119.

Rosen, O.M., 2003. Siberian craton: tectonic zonation and problems of evolution. Geotektonika 3, 1-19.

Rosen, O.M., Serenko, V.P., Spetsius, Z.V., Manakov, A.V., Zinchuk, N.N., 2002. Yakutian kimberlite province: position in the structure of the Siberian Craton and composition of the upper and lower crust. Russian Geology and Geophysics 43, 1-24.

Rosen, O.M., Levskii, L.K., Zhuravlev, D.Z., Rotman, A.Y., Spetsius, Z.V., Makeev, A.F., Zinchuk, N.N., Manakov, A.V., Serenko, V.P., 2006. Paleoproterozoic accretion in the northeast Siberian Craton: isotopic dating of the Anabar collision system. Stratigraphy and Geological Correlation 14, 581-601.

Rosen, O.M., Manakov, A.V., Serenko, V.P., 2005. Paleoproterozoic collisional system and diamondiferous lithospheric keel of the Yakutian kimberlite province. Russian Geology and Geopgysics 46, 1259-1272.

Sahama, T.G., 1981. Growth structure in Ceylon zircon. Bulletin de Mineralogie 104 $89-94$

Shatsky, V.S., Rudnick, R.I., Jagoutz, E., 1990. Mafic granulites from Udachnaya pipe, Yakutia: samples of Archean lower crust? In: Sobolev, N.V. (Ed.), Deep Seated Magmatism and Evolution the Lithosphere of Siberian Platform, pp. 45-46 (Novosibirsk)

Sláma, J., Košler, J., Condon, D.J., Crowley, J.L., Gerdes, A., Hanchar, J.M., Horstwood, M.S.A. Morris, G.A., Nasdala, L., Norberg, N., Schaltegger, U., Tubrett, M.N., Whitehouse, M.J. 2008. Plešovice zircon - a new natural reference material for $\mathrm{U}-\mathrm{Pb}$ and $\mathrm{Hf}$ isotopic microanalysis. Chemical Geology 249, 1-35.

Smith, D.G.W., de St. Jorre, L., Reed, S.J.B., Long, J.V.P., 1991. Zonally metamictized and other zircons from Thor Lake, Northwest Territories. Canadian Mineralogist 29, 301-309.
Sorbier, L., Rosenberg, E., Merlet, C., 2004. Microanalysis of porous materials. Microscopy and Microanalysis 10, 745-752.

Sparks, R.S.J., Baker, L., Brown, R.J., Field, M., Schumacher, J., Stripp, G., Walters, A., 2006. Dynamical constraints on kimberlite volcanism. Journal of Volcanology and Geothermal Research 155, 18-48.

Spetsius, Z.V., Belousova, E.A., Griffin, W.L., O'Reilly, S.Y., Pearson, N.J., 2002. Archean sulfide inclusions in Paleozoic zircon megacrysts from the Mir kimberlite, Yakutia: implications for the dating of diamonds. Earth and Planetary Science Letters 199, 111-126.

Sun, J., Liu, C.-Z., Tappe, S., Kostrovitsky, S.I., Wu, F.Y., Yakovlev, D., Yang, Y.-H., Yang, J.H., 2014. Repeated kimberlite magmatism beneath Yakutia and its relationship to Siberian flood volcanism: insights from in situ $\mathrm{U}-\mathrm{Pb}$ and $\mathrm{Sr}-\mathrm{Nd}$ perovskite isotope analysis. Earth and Planetary Science Letters 404, 283-295.

Suvorov, V.D., Melnik, E.A., Thybo, H., Perchuc, E., Parasotka, B.S., 2006. Seismic velocity model of the crust and uppermost mantle around the Mirnyi kimberlite field in Siberia. Tectonophysics 420, 49-73.

Syme, R.W.G., Lockwood, D.J., Kerr, J., 1977. Raman spectrum of synthetic zircon $\left(\mathrm{ZrSiO}_{4}\right)$ and thorite $\left(\mathrm{ThSiO}_{4}\right)$. Journal of Physics C: Solid State Physics 10, 1335-1348.

Törnroos, R., 1985. Metamict zircon from Mozambique. Bulletin of the Geological Society of Finland 57, 181-195.

Utsunomiya, S., Valley, J.W., Cavosie, A.J., Wilde, S.A., Ewing, R.C., 2007. Radiation damage and alteration of zircon from a $3.3 \mathrm{Ga}$ porphyritic granite from the Jack Hills, Western Australia. Chemical Geology 236, 92-111.

Váczi, T., 2013. A new, simple approximation for the deconvolution of instrumental broadening in spectroscopic band profiles. CORALS-2013: Conference on Raman and Luminescence Spectroscopy, Wien, Austria, July, 2013, pp. 103-104 (Book of abstracts).

Valley, J.W., Kinny, P.D., Schulze, D.J., Spicuzza, M.J., 1998. Zircon megacrysts from kimberlite: oxygen isotope variability among mantle melts. Contributions to Mineralogy and Petrology 133, 1-11.

Vavra, G., Schmid, R., Gebauer, D., 1999. Internal morphology, habit and U-Th-Pb microanalysis of amphibolite-to-granulite facies zircons: geochronology of the Ivrea Zone (Southern Alps). Contributions to Mineralogy and Petrology 134, 380-404.

Vladykin, N.V., Lepekhina, E.A., 2009. The age of unusual xenogenic zircons from Yakutian kimberlites. Doklady Earth Sciences 429, 1451-1456.

Wilson, L., Head III, J.W., 2007. An integrated model of kimberlite ascent and eruption. Nature 447, 53-57.

Zaitsev, A.I., Smelov, A.P., 2010. Isotope Geochronology of Kimberlitic Rocks in the Yakutian Province. IGABM SO RAN (Institut Geologii Almaza i Blagorodnykh Metallov Sibirskogo Otdeleniya Rossijjskojj Akademii Nauk), Yakutsk, (107 pp. (in Russian)).

Zartmann, R.E., Richardson, S.H., 2005. Evidence from kimberlitic zircon for a decreasing mantle Th/U since the Archean. Chemical Geology 220, 263-283.

Zhang, M., Salje, E.K.H., Capitani, G.C., Leroux, H., Clark, A.M., Schlüter, J., Ewing, R.C., 2000. Annealing of a-decay damage in zircon: a Raman spectroscopic study. Journal of Physics: Condensed Matter 12, 3131-3148.

Zheng, J.P., Griffin, W.L., O'Reilly, S.Y., Zhao, J.H., Wu, Y.B., Liu, G.L., Pearson, N., Zhang, M., Ma, C.Q., Zhang, Z.H., Yu, C.M., Su, Y.P., Tang, H.Y., 2009. Neoarchean (2.7-2.8 Ga) accretion beneath the North China Craton: $\mathrm{U}-\mathrm{Pb}$ age, trace elements and $\mathrm{Hf}$ isotopes of zircons in diamondiferous kimberlites. Lithos 112, 188-202. 